\title{
Pemberdayaan masyarakat berkonsep pembangunan berkelanjutan (SDGs) dalam kegiatan kuliah kerja nyata Universitas Gadjah Mada di masa pandemi Covid-19
}

\author{
Djarot Heru Santosa* \\ Fakultas Ilmu Budaya, Universitas Gadjah Mada \\ * djarot_gg@ugm.ac.id
}

\begin{abstract}
Abstrak. Kegiatan ini adalah gerakan pemberdayaan masyarakat yang dilakukan oleh para mahasiswa perguruan tinggi dalam melakukan pelayanan kepada masyarakat di masa Pandemi Covid-19 melalui Kuliah Kerja Nyata (KKN). Tujuannya adalah ikut membantu penanganan dampak Pandemi Covid-19 bagi masyarakat di berbagai sektor, seperti sosial, ekonomi, Pendidikan, seni, budaya, penggunaan IPTEK, khususnya teknologi komunikasi, dan lainnya. Universitas Gadjah Mada (UGM) Yogyakarta berperan serta dalam upaya penanganan dampak Covid-19 tersebut, salah satunya melalui program Kuliah Kerja Nyata-Pembelajaran Pemberdayaan Masyarakat (KKN-PPM) yang disesuaikan dengan situasi dan kondisi yang terjadi di masyarakat. Program KKN-PPM UGM dilaksanakan dalam fase tanggap darurat dan fase pemulihan. Pelaksanaannya berdasarkan Surat Edaran Rektor UGM. Pada fase tanggap darurat dilakukan melalui pendampingan pemahaman dan mitigasi pandemi Covid-19. Sedangkan pada fase pemulihan dampak pandemi Covid-19, penanganannya berkonsep pada 17 (tujuh belas) sasaran pembangunan berkelanjutan (SDGs). Hasil-hasil kegiatan KKN-PPM dalam masa Pandemi Covid-19 menunjukan kontribusi yang nyata dalam penanganan pada masa tanggap darurat maupun masa pemulihan dampak pandemi Covid-19. Pendekatan pelaksanaannya dengan mengedepankan humanities social approach (pendekatan sosial humaniora), yaitu memperhatikan latar belakang masyarakat, unsur lokal, kesetaraan, adat dan budaya, serta kondisi di masyarakat yang dihadapinya.
\end{abstract}

Kata Kunci: pemberdayaan, masyarakat, SDGs, KKN, Covid-19

\begin{abstract}
Gadjah Mada University (UGM) students conducted community empowerment activity in providing service to the community during the Covid-19 Pandemic era through Student Community Services Learning (SCL)Program. The goal was to help deal with the Covid-19 Pandemic impacted the community from various sectors, such as social, economic, education, culture, using various science and technology, especially internet-communication, to support the education. The SCL program is carried out in the emergency response and the recovery phase. The implementation was determined based on the UGM Chancellor's Circular. Operational implementation in the field during the emergency response phase was carried out through assistance in understanding and mitigating the Covid-19 pandemic. The results of SCL activities during the pandemic showed a real contribution in handling the emergency response period and the recovery period of the impact of the Covid-19 Pandemic. The approach is taken by prioritizing the humanities' social approach, namely paying attention to the community's background, local elements, equality, customs, and culture, and the conditions in the society it faces.
\end{abstract}

Keywords: empowerment, community, SCL, Covid-19

To cite this article: Santosa, D. H. 2020. Pemberdayaan masyarakat berkonsep pembangunan berkelanjutan (SDGs) dalam kegiatan kuliah kerja nyata Universitas Gadjah Mada di masa pandemi Covid-19. Unri Conference Series: Community Engagement 2: 317-324. https://doi.org/10.31258/unricsce.2.317-324

(C) 2020 Authors

Peer-review under responsibility of the organizing committee of Seminar Nasional Pemberdayaan Masyarakat 2020 


\section{PENDAHULUAN}

Program Kuliah Kerja Nyata-Pembelajaran Pemberdayaan Masyarakat (KKN- PPM) dikembangkan oleh Universitas Gadjah Mada sebagai bentuk mata kuliah (lapangan) yang salah satu tujuannya adalah mendidik mahasiswa untuk dapat belajar memberi layanan kepada masyarakat secara langsung. Tujuan pelaksanaan KKN-PPM UGM adalah meningkatkan empati dan kepedulian mahasiswa terhadap situasi sosial kemasyarakatan secara langsung, melaksanakan terapan IPTEKS secara teamwork dan interdisipliner, menanamkan nilai-nilai kepribadian (Nasionalisme dan jiwa Pancasila, keuletan, etos kerja dan tanggung jawab kepada mahasiswa.

Program KKN-PPM bagi masyarakat secara luas bermanfaat untuk memperoleh bantuan pemikiran dan tenaga untuk merencanakan serta melaksanakan pengembangan masyarakat, meningkatkan kemampuan berpikir, bersikap, dan bertindak dalam menyelesaikan permasalahan yang dihadapi secara real-time. Dampak kegiatan Program KKN-PPM bagi masyarakat juga akan mendapatkan pembaharuan- pembaharuan yang diperlukan dalam pembangunan pemberdayaan daerah. Para mahasiswa peserta KKN-PPM juga dapat dimanfaatkan untuk bersama-sama dalam membentuk kader-kader pemberdayaan masyarakat.

Di Masa Pandemi Covid-19 sejak bulan Maret 2020, kolaborasi antara mahasiswa KKN-PPM bersama dengan masyarakat mampu mengidentifikasi permasalahan yang ada di masyarakat dan mencari penyelesaiannya dengan memanfaatkan dan memberdayakan sumber daya yang dimiliki (iptek, sumberdaya manusia dan sumber daya alam). Mahasiswa menggerakkan unsur-unsur yang ada di masyarakat agar mampu berswadaya, berswakelola, dan berswadaya dalam pembangunan. Selanjutnya, masyarakat digerakkan agar memiliki kemandirian dalam memenuhi kebutuhan hidup dan melakukan pembangunan secara berkelanjutan.

Program KKN-PPM di masa pandemi dapat mendorong tumbuh dan berkembangnya potensi-potensi yang dimiliki masyarakat untuk mengatasi kondisi kedaruratan maupun pemulihan situasi atas dampak pandemi. Mahasiswa bertugas mengembangkan agen-agen pemberdayaan masyarakat di berbagai aspek, seperti ekonomi, sosial, budaya, dan ekologi (lingkungan) yang dirancang secara terstruktur dan sistematis. Dengan demikian, implementasi program KKN-PPM di masa pandemi bermanfaat untuk menggerakkan dan memulihkan berbagai sektor terdampak pandemi Covid-19.

\section{METODE PENERAPAN}

Kekuatan implementasi pelaksanaan KKN-PPM UGM dalam penanganan Pandemi Covid-19 ini karena didasarkan atas metode pemberdayaan masyarakat. Kegiatan pemberdayaan masyarakat difokuskan pada penguatan individu anggota masyarakat beserta pranata-pranatanya. Pendekatan utama dalam konsep pemberdayaan ini adalah menempatkan masyarakat tidak sekedar sebagai objek melainkan juga subyek (Suparjan dan Suyatno, 2003). Konsep Pemberdayaan Masyarakat dan teknis implementasi melalui KKN dilakukan dengan memperkuat potensi atau daya (empowering), dan terciptanya kemandirian. Tujuan pemberdayaan masyarakat adalah untuk membentuk individu dan masyarakat menjadi mandiri. Hasil yang diharapkan adalah tumbuhnya kompetensi masyarakat (tanggung jawab sosial dan kapasitas masyarakat). Pemberdayan memberikan tekanan pada otonomi pengambilan keputusan dari suatu kelompok masyarakat. Pendekatan pemberdayaan masyarakat merupakan antitesis atau kebalikan dari pendekatan yang bersifat sentralistis dan top down.

Pendekatan Pemberdayaan merupakan derivasi dari perspektif people centered development. Pemberdayaan memiliki dua makna yaitu to give authority to dan to give ability to or enable. Pengertian to give authority to, artinya bahwa pemberdayaan memiliki makna memberikan kekuasaan, mengalihkan kekuatan dan mendelegasikan otoritas ke pihak lain, sedangkan pengertian to give ability to or enable, adalah pemberdayaan diartikan sebagai upaya untuk memberi kemampuan atau keberdayaan. Tahap-tahap kegiatan pemberdayaan masyarakat yang dapat dilakukan oleh mahasiswa ketika melaksanakan KKN-PPM, adalah pertama, tahap penyadaran dan pembentukan perilaku menuju perilaku sadar dan peduli sehingga merasa membutuhkan peningkatan kapasitas diri. Kedua, tahap transformasi kemampuan berupa wawasan pengetahuan, kecakapan-keterampilan agar terbuka wawasan dan memberikan keterampilan dasar sehingga dapat mengambil peran dalam pembangunan. Tahap ketiga, adalah peningkatan kemampuan intelektual, kecakapan-keterampilan sehingga terbentuk inisiatif dan kemampuan inovatif untuk mengantarkan pada kemandirian.

Dubois dan Miley (1999) menjelaskan teknik-teknik pemberdayaan masyarakat yang bisa dilakukan diarahkan untuk membangun sistem pertolongan yang dapat merefleksikan respon empati, menghargai pilihan yang dihadapi dalam menentukan nasibnya sendiri, menghargai perbedaan dan keunikan masing-masing 
individu, serta menekankan kerjasama antar pihak yang dihadapi. Untuk memperlancar pelaksanaan dan implementasi kegiatan pemberdayaan masyarakat, agen penggerak harus dapat membangun komunikasi yang baik antar pihak dengan cara, antara lain menghormati martabat dan harga diri klien, mempertimbangkan keragaman individu, berfokus pada klien, dan menjaga kerahasiaan klien. Pihak penggerak pemberdayaan masyarakat harus memiliki inisiatif dan inovasi dalam pemecahan masalah dengan cara memperkuat partisipasi, menghargai hak-hak individu, menjelaskan bahwa tantangan-tantangan sebagai sebuah kesempatan, dan keterlibatan antar pihak dalam pembuatan keputusan dan evaluasi.

\section{HASIL DAN KETERCAPAIAN SASARAN}

Uraian berikut ini adalah bentuk kegiatan dan pembahasannya pemberdayaan masyarakat melalui program KKN-PPM UGM di masa Pandemi Covid-19 yang pelaksanaanya berdasar pada 17 (tujuh belas) sasaran program pembangunan berkelanjutan (SDGs). Bentuk kegiatannya disesuaikan dengan masa atau fase penanganan pandemi, yaitu masa penanganan tanggap darurat dan masa pemulihan dampak pandemi.

\section{Masa Tanggap Darurat (Periode Maret - Mei 2020)}

Pada masa-masa awal wabah virus Corona masuk di wilayah Indonesia, yang kemudian disebut Pandemi Covid-19, kepekaan civitas akademika Universitas Gadjah Mada telah muncul. Pada tanggal 11 Maret 2020, UGM menerjunkan sekitar 60 mahasiswa KKN-PPM di wilayah Propinsi Daerah Istimewa Yogyakarta. Setelah sekitar 10 hari di lokasi KKN, Pemerintah Indonesia mengumumkan tanggap darurat atas wabah atau Pandemi Covid-19 secara nasional, demikian pula kebijakan Pemerintah Daerah Provinsi DIY dan otoritas kampus UGM juga mengeluarkan maklumat yang sama. Berdasar peraturan tersebut, pengelola menarik seluruh mahasiswa KKN-PPM dari lokasi meskipun baru berlangsung sekitar sepuluh hari.

Sebagai bentuk respon maklumat Pemerintah pada saat itu, UGM mengubah kebijakan pelaksanaan KKN oleh mahasiswa menjadi semacam kegiatan kerelawanan masa tanggap darurat pandemi Covid-19 di beberapa lokasi KKN dan bekerjasama dengan Satgas Penanganan Covid-19 dari UGM dan Propinsi DIY. Pada masa ini, mahasiswa KKN melakukan kegiatan sosialisasi dan penerangan umum tentang virus corona dan bagaimana penanganannya.

Mahasiswa KKN bersama-sama dengan Satgas dan sinergi dengan beberapa pihak juga membantu membangun komunikasi kepada unsur-unsur masyarakat untuk menenangkan dari situasi kepanikan pada masa itu. Penyebaran informasi dari hasil inovasi para mahasiswa ini dilakukan baik melalui media sosial, poster, spanduk, baliho, bahkan sampai melakukan penerangan secara mobile keliling ke desa-desa yang sulit terjangkau jaringan komunikasi. Kegiatan ini dilatarbelakangi atas ketiadaan informasi yang jelas dan akurat tentang kondisi terbaru terkait wabah Covid-19 di wilayahnya.

Sebagai tindak lanjut membantu penanganan pada masa tanggap darurat pandemi Covid-19, serta menjamin keberlanjutan kegiatan KKN periode sebelumnya, UGM kembali menerjunkan mahasiswa KKN periode khusus pada tanggal 4 Mei sampai dengan 22 Juni 2020. Hal ini dilatarbelakangi situasi dimana ketersediaan masker, hand sanitizer, face shields serta alat pelindung diri bagi masyarakat pada umumnya, dan khususnya para tenaga kesehatan terkendala pasokan. Oleh karena itu, pada masa tanggap darurat tahap ini, mahasiswa KKN UGM bersama-sama dengan pihak lain membantu penghimpunan dana untuk pembelian bantuan alat dan sarana yang diperlukan mencukupi kebutuhan tersebut di wilayah-wilayah terjangkau. Mahasiswa membantu pengadaan masker, hand sanitizer, dan face shields dengan cara memproduksi sendiri, sampai dengan pendistribusiannya. Pelaksanaannya bersinergi dengan beberapa pihak yang peduli kondisi pada masa tersebut. Di samping masih gencar bersosialisasi mengenai Covid-19 ke masyarakat dan kelompok-kelompok rentan, beberapa mahasiswa KKN juga menginisiasi dengan membuat aplikasi kawalrumasakit.id untuk merangkum semua data dan informasi tentang kejadian COVID-19 pada masa darurat tersebut, baik terkait jumlah dan status pasien, rumah sakit yang memberikan pelayanan, dan ketersediaan alat pelindung diri dan alat pendukung perawatan bagi pasien di masing-masing fasilitas pelayanan kesehatan. 


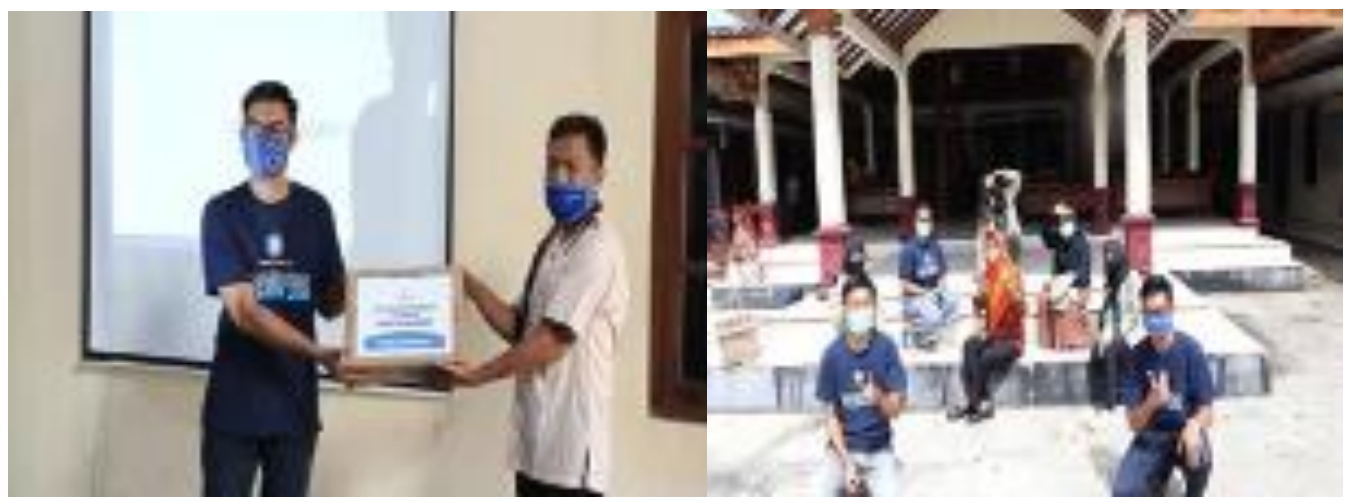

Gambar 1. Kegiatan Mahasiswa KKN-PPM UGM Sosialisasi Edukasi Covid-19 serta penyaluran bantuan kepada warga Desa Bedoyo Gunungkidul DIY (Dok. KKN UGM, April 2020)

Di bidang sosialisasi dan edukasi ke masyarakat awam tentang virus Corona atau Covid-19 dan tata cara menghindarinya dengan melalui hidup sehat, disampaikan melalui berbagai sarana media komunikasi.
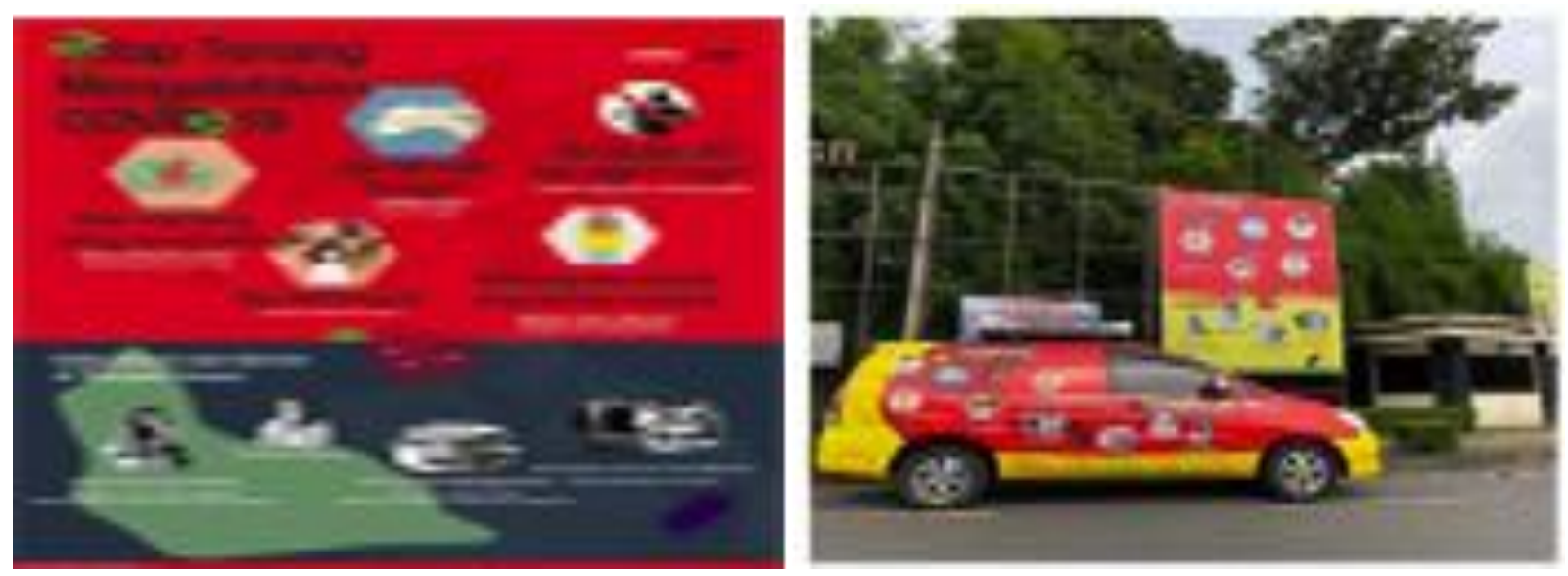

Gambar 2. Poster yang dibuat Tim KKN UGM dengan memanfaatkan dua bahasa untuk memudahkan pemahaman Masyarakat mobi penerangan keliling DPKM UGM (Dok. KKN UGM, Maret 2020)

Bentuk program sosialisasi \& edukasi seputar Pandemi Covid-19 pada periode bulan Maret s.d. Mei 2020 berupa poster dan video edukasi disebarkan ke seluruh ketua RW di Kelurahan/Desa, melalui aplikasi WhatsApp (WA). Kegiatan ini dilakukan efektif dengan menggerakkan unsur masyarakat seperti Ketua RW dan RT untuk menyebarkannya ke grup WA RW dan RT di wilayahnya. Selain itu, konten-konten sosialisasi juga diunggah melalui Instagram bersama. Kegiatan membantu logistik di awal pandemi Covid dilakukan oleh Mahasiswa KKN, mahasiswa relawan Covid-19, dosen pembimbing, Satgas Covid-19 dari universitas dan lainnya membuat dan mendistribusikan masker, hand sanitizer dan face shield. Berbagai bentuk hasil dan ketercapaian sasaran kegiatan pemberdayaan masyarakat melalui KKN di masa pandemi ini tergambar dalam foto-foto dokumentasi hasil berikut ini.
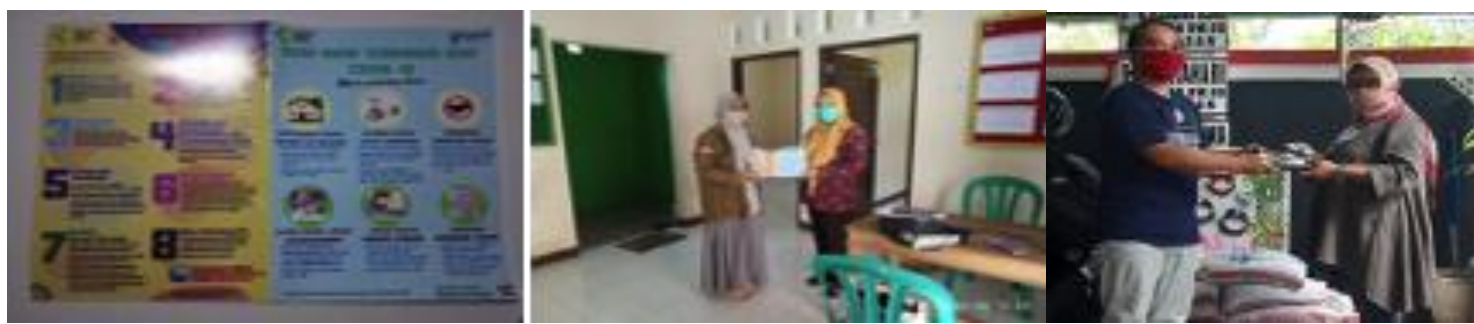

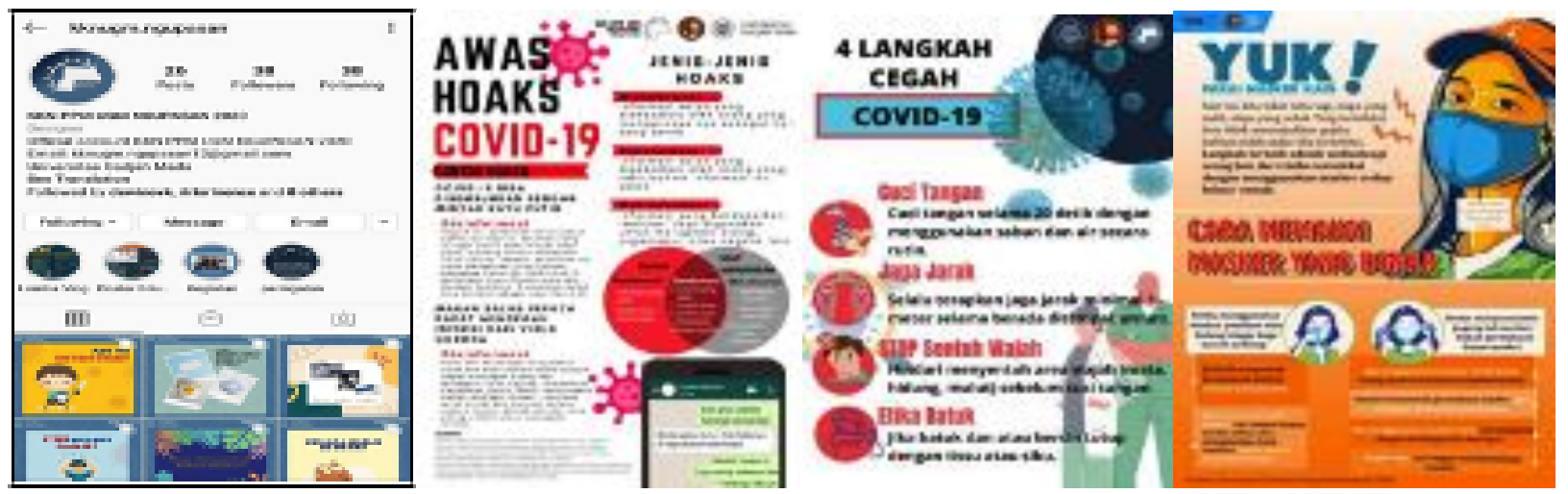

Gambar 3. Hasil-hasil kegiatan mahasiswa KKN-PPM UGM pada Masa Tanggap Darurat Periode bulan Maret - Mei 2020 (Dok. KKN UGM, Mei 2020)

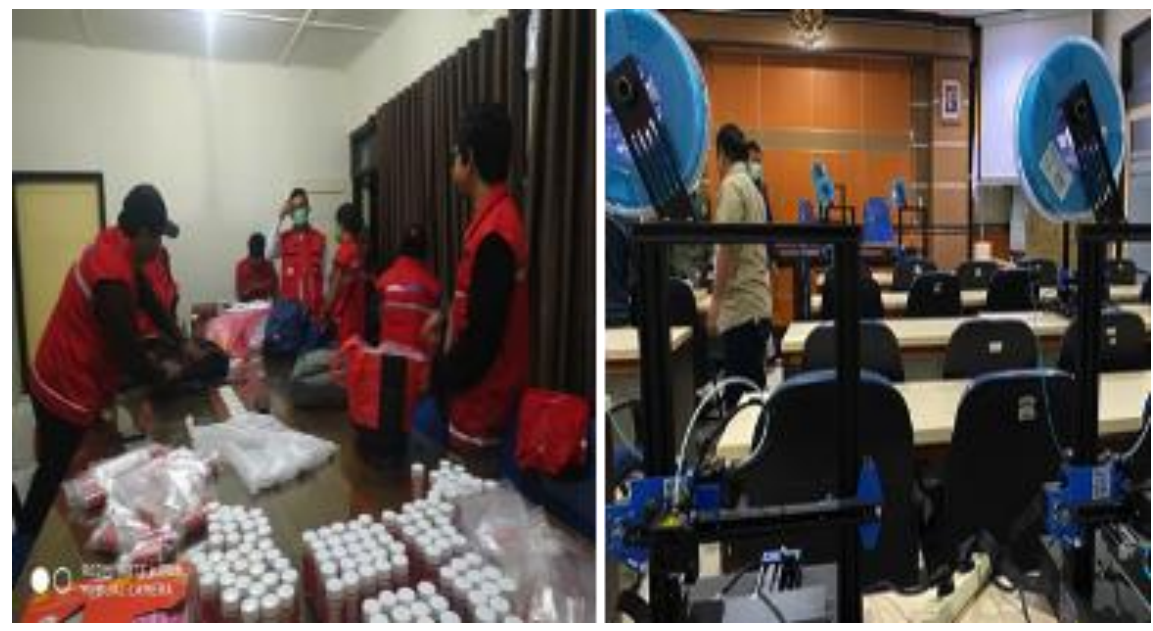

Gambar 4. Hasil-hasil kegiatan mahasiswa KKN-PPM UGM memproduksi logistik bantuan pada Masa Tanggap Darurat Periode bulan Maret - Juli 2020 (Dok. KKN UGM, Juli 2020)

Hal paling menarik yang dilakukan oleh mahasiswa KKN dalam masa tanggap darurat ini adalah semangat dalam memberi edukasi di masa yang sulit terduga dalam situasi pandemi Covid-19. Koordinasi dilakukan melalui komunikasi daring baik media internet maupun media sosial lainnya. Kegiatan daring ini juga untuk kegiatan sosialisasi, Focus Group Discussion (FGD), menyampaikan infografis. Video tutorial, dan lainnya.

\section{Masa Pemulihan (Periode Juni - September 2020)}

Kegiatan pemberdayaan masyarakat melalui Program KKN-PPM UGM dalam penanganan Pandemi Covid19 pada masa pemulihan dilakukan dengan membantu menggerakan masyarakat untuk menghadapi kondisi pandemi. Untuk memudahkan pelaksanaan kegiatan, analisis permasalahan dilakukan agar bantuan dan pendampingan tepat sasaran. Sesuai komitmen UGM dalam pembangunan berkelanjutan (SDGs) maka tujuan pelaksanaan KKN-PPM UGM di masa pandemi Covid-19 ini diarahkan untuk menyelesaikan permasalahanpermasalahan sesuai 17 goals (tujuan) dalam SDGs. Beberapa permasalahan dari analisis dampak pandemi Covid-19 yang terjadi pada masa pemulihan ini sesuai tujuan pembangunan berkelanjutan, antara lain.

a. Masyarakat yang kehilangan pendapatan, menyebabkan segmen masyarakat dan keluarga rentan berada di bawah garis kemiskinan (SDGs nomor 1, Penanganan Kemiskinan);

b. Produksi dan kontribusi makanan terganggu (SDGs nomor 2, Penanganan Kelaparan);

c. Efek Kematian pada Kesehatan seseorang, (SDGs nomor 3, Kesehatan)

d. Banyak sekolah diliburkan, pembelajaran jarak jauh kurang efektif dan tidak dapat diakses oleh sebagian orang, (SDGs nomor 4, Pendidikan);

e. Keluhan perempuan tentang ekonomi menimbulkan resiko dan meningkatnya tingkat kekerasan terhadap perempuan. Mayoritas perempuan merupakan pekerja kesehatan dan pekerja sosial yang lebih mudah terpapar Covid-19, (SDGs nomor 5, Kesetaraan gender); 
f. Gangguan pasokan dan akses yang tidak memadai terhadap air bersih menghalangi akses fasilitas cuci tangan yang bersih, yang merupakan salah satu langkah pencegahan yang paling penting, (SDGs nomor 6, Air bersih dan sanitasi);

g. Kekurangan pasokan dan personel akan mengarah pada gangguan akses listrik, lebih lanjut lemahnya respons dan kapasitas sistem kesehatan, (SDGs nomor 7, Energi);

h. Kegiatan ekonomi ditangguhkan, pendapatan lebih rendah, lebih sedikit waktu kerja, pengangguran untuk pekerjaan tertentu, (SDGs nomor 8, Pekerjaan yang Layak dan Pertumbuhan Ekonomi)

i. Banyaknya pekerja industri yang dirumahkan/di PHK dan berhentinya pekerjaan-pekerjaan infrastruktur dimana dana dialihkan untuk menangani covid-19, menyebabkan banyaknya pengangguran, (SDGs nomor 9, Pekerjaan dan Industri);

j. Semakin tingginya kesenjangan, misalnya, tidak bisa mengakses kebutuhan internet, kekurangan Alat Pelindung Diri (APD), akses di beberapa daerah, dan permasalahan lain yang semakin memperparah kesenjangan, (SDGs nomor 10);

k. Populasi yang tinggal di daerah kumuh menghadapi risiko lebih tinggi karena kepadatan populasi yang tinggi dan kondisi sanitasi yang buruk, (SDGs nomor 11);

1. Adanya kelangkaan terhadap beberapa barang dan produk dan pembatasan sehingga tidak dapat memproduksi produk/bekerja secara maksimal, (SDGs nomor 12);

m. Aksi memerangi perubahan iklim berkurang, polusi terhadap lingkungan lebih sedikit karena produksi dan transportasi yang kurang, (SDGs nomor 13);

n. Bumi, lingkungan, dan udara menjadi lebih bersih, namun dampak penggunaan desinfektan yang tidak tepat mengakibatkan pencemaran lingkungan (tanah dan air), (SDGs nomor 14 dan 15);

o. Langkah-langkah efektif untuk mencegah konflik antar makhluk hidup, mereka yang berada di daerah konflik paling berisiko menderita kerugian, (SDGs nomor 16);

p. Memperburuk pencegahan terhadap globalisasi, tetapi juga menyoroti pentingnya kerja sama internasional pada kesehatan masyarakat, (SDGs nomor 17).

Berdasar analisis di atas, berikut ini gambaran hasil kegiatan KKN-PPM UGM di masa pandemi. Di masa pemulihan bentuk poster dan infografis dibuat dan disebarkan oleh mahasiswa KKN UGM untuk membangkitkan ekonomi rakyat secara sederhana, pendampingan membantu pengemasan produk-produk makanan yang tidak tahan lama waktu pemakaiannya, serta mengajarkan pemasaran produk lewat media sosial sederhana, yaitu whatsapp. Kegiatan ini merupakan jawaban untuk sasaran SDGs nomor 1- 10; 12, dan 16.

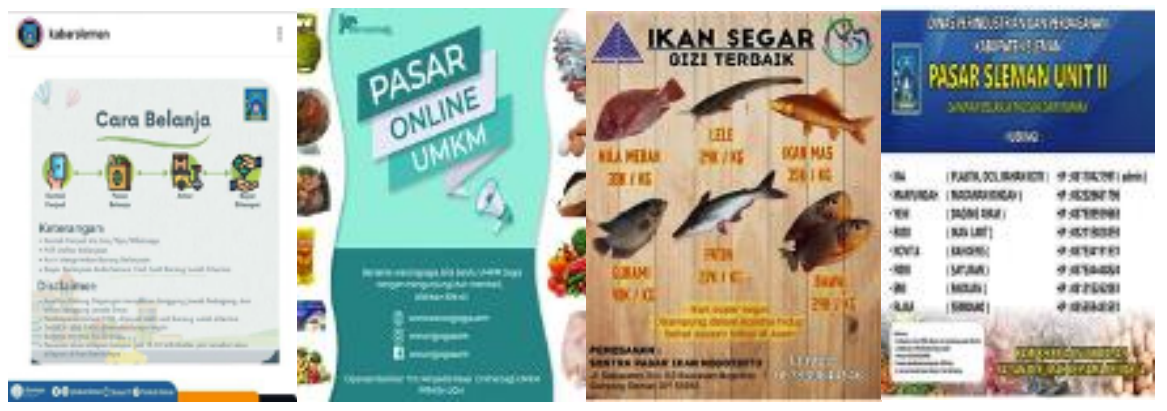

Gambar 5. Kegiatan untuk SDGs nomor 1-10; 12, 14,15, dan 16

Gambar-gambar di bawah ini menunjukan dokumentasi aktivitas kegiatan KKN-PPM UGM di berbagai sektor, diantaranya memberi pelatihan penggunaan teknologi informatika berupa internet dan media sosial lain untuk pemasaran produk pedagang kecil, pembuatan dan penyebaran poster, dan pendampingan di sektor agro. Kegiatan di atas merupakan jawaban untuk SDGs nomor 1 -10; 12, 14,15, dan 16. 


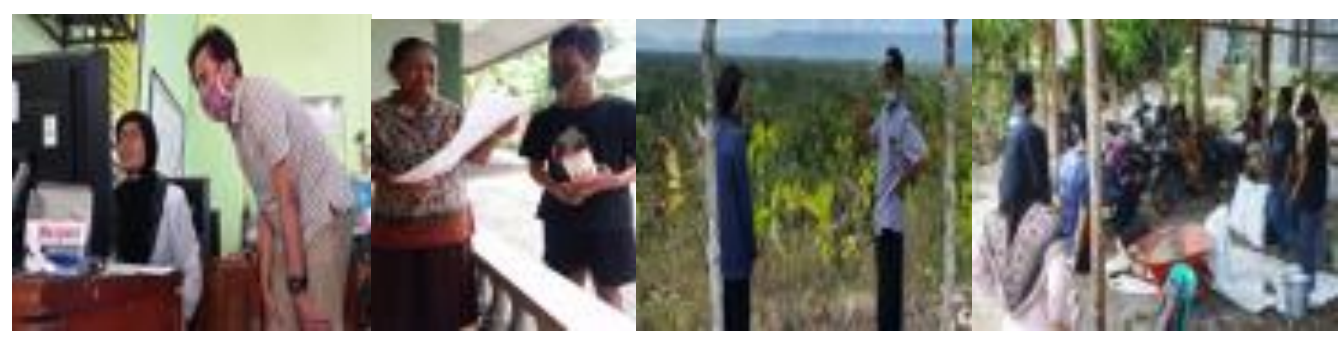

Gambar 6. aktivitas kegiatan KKN-PPM UGM di berbagai sektor

Di bidang pendidikan pada masa darurat dan pemulihan penangan dampak Covid-19, kegiatan KKN-PPM UGM difokuskan pada bantuan pembimbing belajar bagi siswa sekolah dasar dan menengah. Pelaksanaannya dengan luring atau tatap muka langsung maupun terbatas, dilakukan di sekolah, di rumah, atau di tempat umum yang terjangkau selama kondisi memungkinkan dan menggunakan protokol kesehatan yang ketat. Berikut adalah gambaran kegiatannya.
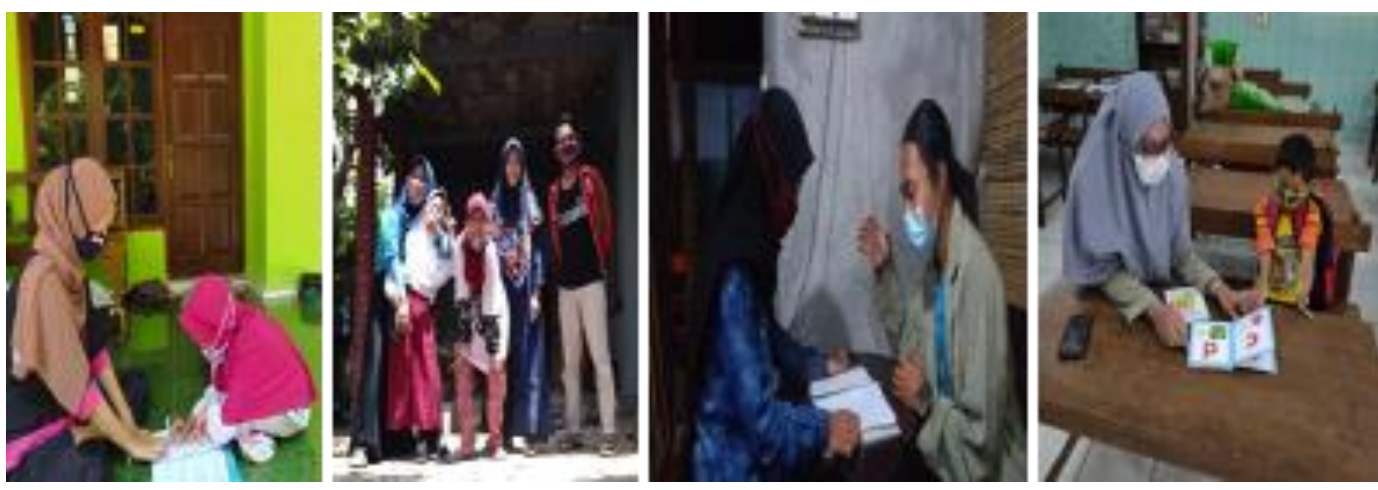

Gambar 7. Kegiatan KKN-PPM UGM dalam bimbingan belajar bagi siswa sekolah dasar dan menengah

Di samping menyasar ke siswa, para mahasiswa pun membantu mendampingi guru-guru untuk membuat materi pembelajaran selama proses pembelajaran media daring. Transfer pengetahuan mengenai penggunaan teknologi informatika dalam proses pembelajaran merupakan sesuatu yang bermanfaat bagi guru maupun siswanya.

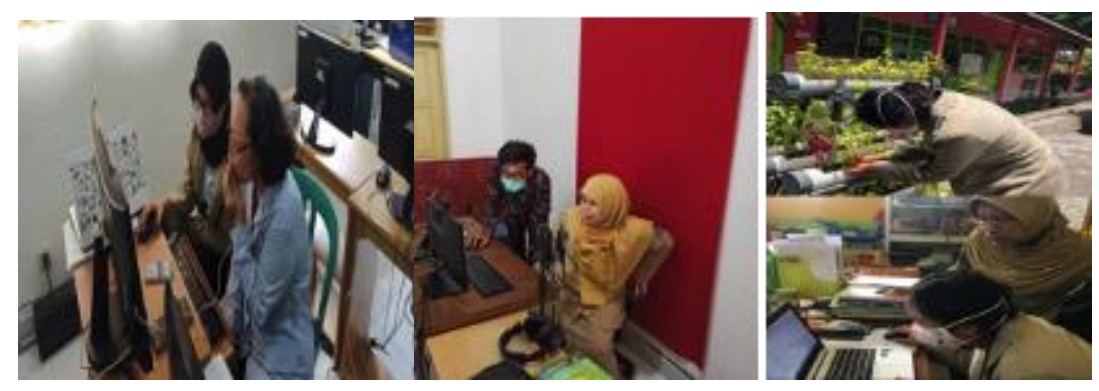

Gambar 8. dokumentasi mahasiswa KKN-PPM UGM mendampingi guru membuat media pembelajaran Daring (Dok. KKN UGM, Agustus 2020)

Kegiatan pendampingan penanganan pemulihan di sektor pendidikan ini sesuai tujuan SDGs ke-3 danke4. Inovasi lain dari pendampingan pemulihan pada masa pandemi Covid-19 ini dilakukan secara terencana oleh mahasiswa KKN untuk mengisi waktu luang sekaligus melawan kejenuhan bagi para pelajar dan masyarakat umum. Kegiatan tersebut diwujudkan dengan berbagai lomba yang aman pada masa pandemi. 


\section{KESIMPULAN}

Berdasar uraian di atas, rekomendasi beberapa bentuk kegiatan penanganan pemulihan pada masa pandemi Covid-19 yang bisa dilakukan oleh mahasiswa dan generasi muda lainnya, antara lain.

1. Penanganan resesi ekonomi - melalui program "Bela-beli hasil sendiri",

2. Pendampingan pembelajaran secara daring dan belajar dari rumah,

3. Ketahanan pangan dan pengolahan hasil pertanian,

4. Pengembangan peluang berusaha dan bekerja,

5. Pola hidup bersih dan sehat,

6. Tatanan baru di era new normal,

7. Membangkitkan Usaha Mikro Kecil dan Menengah (UMKM),

8. Pemanfaatan teknologi informatika (IT),

9. Penanganan dampak sosial di keluarga dan masyarakat,

10.Pemberdayaan wanita.

Pendekatan yang tepat menjadi kunci suksesnya, inovasi, dan kreativitas serta menyesuaikan dengan kondisi yang ada di masyarakat. Bekal ilmu pengetahuan yang diperoleh peserta KKN-PPM dari bangku perkuliahan menjadi amunisi dalam mengembangkan inovasi dan kreativitas selama pelaksanaannya. Kondisi yang baik tersebut menjadikan unsur mahasiswa berperan penting dalam kegiatan pemberdayaan masyarakat masa kini, oleh sebab itu tidaklah berlebihan jika mahasiswa merupakan unsur penggerak kegiatan pemberdayaan masyarakat.

\section{UCAPAN TERIMA KASIH}

Diucapkan terima kasih kepada segenap Pimpinan Direktorat Pengabdian kepada Masyarakat Universitas Gadjah Mada, Sub Direktorat KKN UGM, Dosen Koordinator Wilayah, Dosen Pembimbing Lapangan (DPL), dan Seluruh Mahasiswa peserta KKN UGM Periode 1, 2, 3, 6, dan 7 tahun 2020.

\section{DAFTAR PUSTAKA}

Dadang Juliantara. 2002. Pembaruan Desa: Bertumpu pada Apa yang Terbawa. Yogyakarta: Lapera Pustaka Utama

Dubois, Brenda \& Karla K. Miley. 2005. Social Work an Empowered Profession. USA: USA. Pearson.

Sedarmayanti. 2001. Sumber Daya Manusia dan Produktivitas Kerja. Bandung: Mandar Maju.

Soetomo. 2006. Strategi-strategi Pembangunan Masyarakat. Yogyakarta: Pustaka Pelajar

Suparjan \& Hempri Suyatno. 2003. Pengembangan Masyarakat dari pembangunan Sampai Pemberdayaan. Yogyakarta: Aditya Media.

Syahza, A. 2019. "Dampak nyata pengabdian perguruan tinggi dalam membangun negeri”. Unri Conference Series: Community Engagement, 1, 1-7. https://doi.org/10.31258/unricsce.1.1-7

Tim Penyusun. 2013. Buku Pedoman Kuliah Kerja Nyata Pembelajaran Pemberdayaan Masyarakat (KKN-PPM) Universitas Gadjah Mada. Yogyakarta: Lembaga Penelitian dan Pengabdian Kepada Masyarakat UGM. 